\title{
Evaluation of Chemical Properties of Dredged Materials, Paranagua Port, Brazil, According to Dredging Legislation CONAMA 454/2012
}

\author{
Andre Marcal Kanashiro ${ }^{1, *}$, Jian Xie ${ }^{1,2}$ \\ ${ }^{1}$ School of Environmental Engineering, South China University of Technology, China \\ ${ }^{2}$ The South China Sea Marine Engineering and Environment Institute, China
}

Copyright $\bigcirc 2016$ by authors, all rights reserved. Authors agree that this article remains permanently open access under the terms of the Creative Commons Attribution License 4.0 International License

\begin{abstract}
This paper discusses chemical and physical analyses of Paranagua Port's dredged material based in the relevant dredging legislation in Brazil, Conama $\mathrm{N}^{0} 454 / 2012$. It was analyzed samples before dredging activity of Paranagua Port's berth. Most of samples had concentrations below Level 1 established by CONAMA Resolution No. 454/2012. However, considering the nature of these contaminations, we can suggest that losses during the operations of loading / unloading, storage and transfer of products in Paranagua Port, constitute sources of polluting materials into waters of the berth samples. Most of contamination may come from fertilizers as Paranagua Port exports grains and imports fertilizer to control food production.
\end{abstract}

Keywords Conama 454/2012, Dredging Sediment, Chemical Analyses, Dredging Legislation

\section{Introduction}

Dredging is an excavation activity usually carried out at least partly underwater, in shallow seas or freshwater areas with the purpose of gathering up bottom sediments and disposing of them at a different location, Bray et al. [1]. This technique is often used to keep waterways navigable. It is also used as a way to replenish sand on some public beaches, where sand has been lost because of coastal erosion.

Dredging can create disturbance to aquatic ecosystems, often with adverse impacts. In addition, dredge spoils may contain toxic chemicals that may have an adverse effect on the disposal area; furthermore, the process of dredging often dislodges chemicals residing in benthic substrates and injects them into the water column.

However, according to et al IADC [2], 90\% of the dredged material in the world has low level of contamination and is thus likely to be used for beneficial purposes. Given the laws of each country, the environmental impacts arising from the disposal of dredged material should be evaluated, trying to, where possible, alternatives to increase its beneficial use and ways to reduce the adverse effects of disposing this material.

There is a growing interest in the use of dredged material as a valuable natural resource, since not only the volume is progressively increasing, as urban development areas neighboring maritime regions allows the use of sediment from different types of projects such as construction of Hong Kong International Airport and Singapore International Airport.

The range of applications for dredged material is now quite varied. Beneficial use includes a variety of options that utilize the material for some productive purpose, such as habitat restoration, agriculture, landfill cover, shoreline stabilization or beach nourishment [3]. According to Huang Huamei et al. [4] combination of dredged marine materials treatment with coastal ecological engineering also has potential opportunities to guarantee the sustainable development of the marine industry.

Sediments have been widely used as environmental indicators because they have great ability to incorporate and accumulate some contaminants. As sediments are carried by rivers to another watercourse or the sea, analyze of sediments at various points in a region of interest are used to track sources of contamination or monitor these contaminants [5].

However, the beneficial use of dredged material mainly depends on its composition and its particle size distribution. This research aims to analyze dredged material from Paranagua Port in order to meet the limits of chemical requirements from National Environmental Council and find a beneficial use alternative for dredged material instead of treating it as disposal sediment.

\section{Dredging Material Legislation}

Pollution of sediments is often connected with pollution of 
water and comes from several sources: domestic sewage, industrial effluents, agricultural and urban diffuse load. The situation is more critical in regions where there are urban port activities, industrial waste and deposit. Dredged materials near estuaries surrounded by industries, for example, can be contaminated by industrial effluents and may have high concentration of several heavy metals such $\mathrm{Cd}, \mathrm{Ni}, \mathrm{Pb}$ and $\mathrm{Cr}$ [6] which can aggravate the problem of environmental pollution if transferred to the end disposal site and contaminate the food chain.

According to Bridges et al. [7], some metals, in particular mercury and various organic compounds, have great power of concentration in the food chain. Cases of Minimata disease were reported in Japan [8]. The disease affects the brain, causing insanity and leading to death, as a result of pollution of water by industrial effluents containing methyl-mercury.

The approval of the disposal site is increasingly restricted since the dredged sediments, mainly resulting from the maintenance of harbors, canals, rivers and lakes, may have medium or high degree of contamination [9]. Therefore, license permit to dredging projects can take years to be issued in Brazil because dredging activities were neglected for many years due to causes related to environmental impacts.

CONAMA - National Environmental Council, through the new Resolution 454/2012, established guidelines and procedures to evaluate dredge material in Brazilian waters, with the goal of supporting environmental licensing of dredging activities and defining locations for final disposal according to the levels of sediment contamination. CONAMA 454/2012 et al. [10] covers ports, bays, rivers, ponds, canals and sea areas, defining rules for sediment analysis before carrying out dredging works. Every dredging project requires license permit to be executed. Port authorities must provide to Environmental Department a Management Plan containing investigation of dredge material according to CONAMA procedures and disposal site or beneficial use of dredge material. According to Management Plan, Environmental Department will analyze all results and consider if any other sample investigation is necessary to finally issue license permit.

Classification of the material to be dredged and quality criteria are defined from two levels according to procedures established by CONAMA 454/2012 (table 1 bellow):

- Level 1: results below Level 1 are expected low probability of adverse effects to biota.

- Level 2: results above Level 2 are predicted a likely adverse effect on the biota.

Regarding Total Organic Carbon (TOC), Total Nitrogen (TN) and Total Phosphorus (TP), a value alert was established to define limit tolerance for these nutrients (table
2 below).

Table 1. Level of Chemical classification of dredge material, according to procedures established by CONAMA 454/2012.

\begin{tabular}{|c|c|c|c|}
\hline \multicolumn{2}{|c|}{ Substances } & \multicolumn{2}{c|}{$\begin{array}{c}\text { Classification of material to } \\
\text { be dredged (dry matter) }\end{array}$} \\
\cline { 2 - 4 } \multicolumn{1}{|c|}{} & Level 1 & Level 2 \\
\hline \multirow{4}{*}{ Metals (mg/kg) } & $\mathrm{As}$ & 19 & 70 \\
\cline { 2 - 4 } & $\mathrm{Cd}$ & 1,2 & 7,2 \\
\cline { 2 - 4 } & $\mathrm{Pb}$ & 46,7 & 218 \\
\cline { 2 - 4 } & $\mathrm{Cu}$ & 34 & 270 \\
\cline { 2 - 4 } & $\mathrm{Cr}$ & 81 & 370 \\
\cline { 2 - 4 } & $\mathrm{Hg}$ & 0,3 & 1,0 \\
\cline { 2 - 4 } & $\mathrm{Ni}$ & 20,9 & 51,6 \\
\cline { 2 - 4 } & $\mathrm{Zn}$ & 150 & 410 \\
\hline
\end{tabular}

Table 2. Guiding values for total organic carbon and nutrient

\begin{tabular}{|c|c|}
\hline PARAMETERS & ALERT VALUE \\
\hline TOC $(\%)$ & 10 \\
\hline $\mathrm{TN}(\mathrm{mg} / \mathrm{kg})$ & 4800 \\
\hline $\mathrm{TP}(\mathrm{mg} / \mathrm{kg})$ & 2000 \\
\hline
\end{tabular}

\section{Material and Method}

\subsection{Paranagua Port, Brazil}

Paranagua Port is located in the South of Brazil and its size and capacity of handling different kind of cargos made it one of the most important to economy (figure 1).

The Port of Paranagua port is the largest exporter of agricultural products from Brazil, with emphasis on soybeans and soybean meal. Export and import grain, fertilizer, containers, liquids, automobiles, wood, paper, salt, and sugar, among others. Most ships countries are from the United States, China, Japan and South Korea.

The entry bar has a width of $200 \mathrm{~m}$ and depth of $12 \mathrm{~m}$. The port has three access channels: the North, the South East and the Shag, the latter, the principal, $28.5 \mathrm{~km}$ in length, width ranging from $150 \mathrm{~m}$ to $200 \mathrm{~m}$ and depth of $13 \mathrm{~m}$ [11].

Paranagua Port always faced a critical situation regarding operational activities in berths due to the intense processes of sedimentation in this region. According to Coelho et al. [12], sediments are part of the hydrological cycle, depending on their chemical composition and adsorption characteristics, may have a high capacity for accumulation of organic and inorganic contaminants. Besides, sediments are not only a major source of water pollutants, but also serve as catalysts, as carriers and as fixatives to other polluters. 


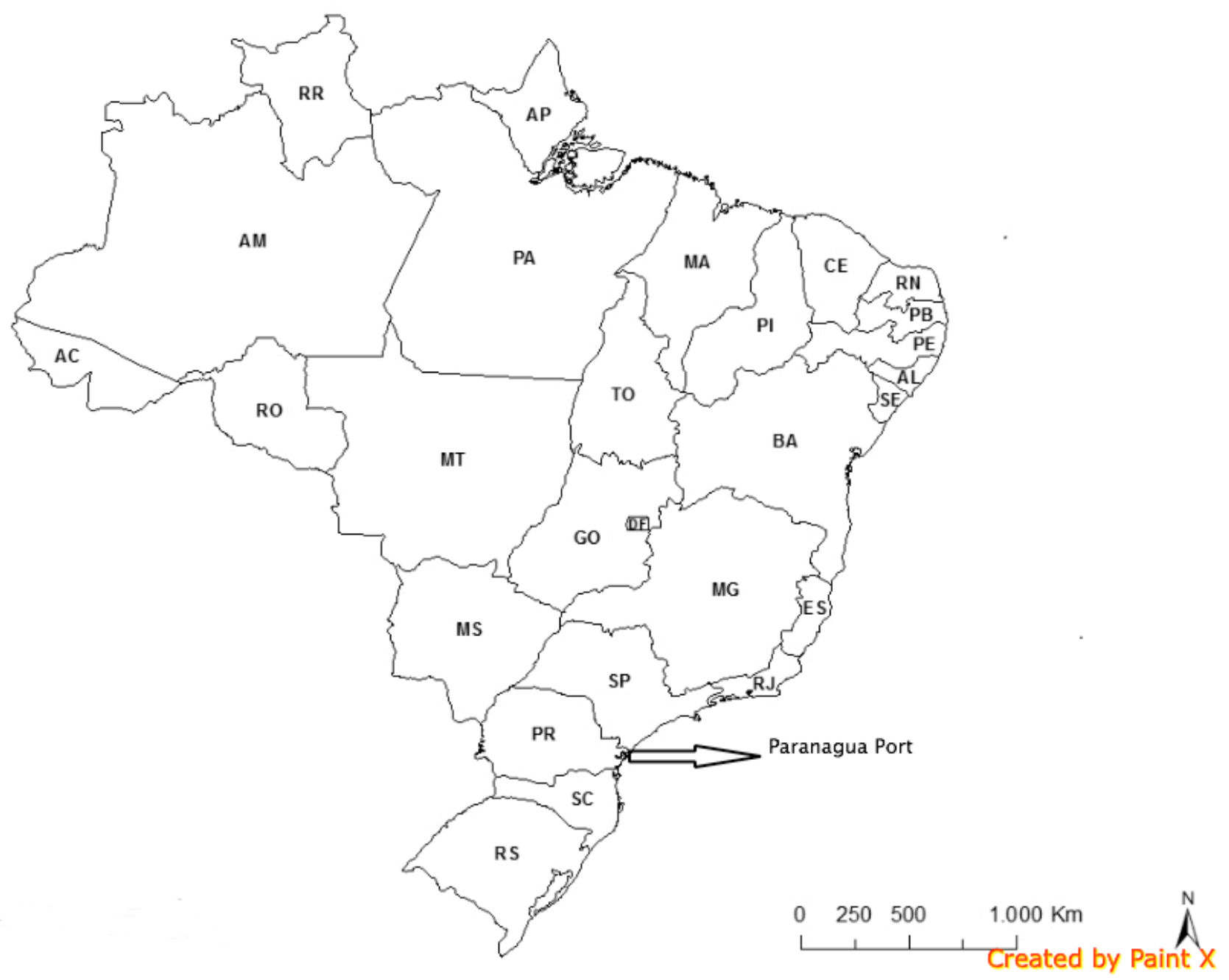

Figure 1. Brazil Map showing Paranagua Port in the South of Brazil

\subsection{Material Collection}

In this study case in Paranagua Port, 8 (eight) samples were analyzed, 5 (five) samples (\#1, \#2, \#3, \#4,\#5) in the area studied to be the disposal site and 3 (three) samples (\#6, $\# 7, \# 8$ ) in the berth area to be dredged.

Table 3. Location of samples in the disposal area \#1, \#2, \#3, \#4, \#5 and in the berth area $\# 6, \# 7, \# 8$.

\begin{tabular}{|c|c|c|}
\hline \multirow{2}{*}{ Sample Sites } & \multicolumn{2}{|c|}{ Location (UTM) } \\
\cline { 2 - 3 } & N & E \\
\hline$\# 1$ & 786647 & 7158148 \\
\hline$\# 2$ & 787797 & 7157128 \\
\hline$\# 3$ & 788788 & 7158148 \\
\hline$\# 4$ & 787835 & 7159213 \\
\hline$\# 5$ & 787769 & 7158110 \\
\hline$\# 6$ & 751542 & 7177285 \\
\hline$\# 7$ & 749993 & 7177579 \\
\hline$\# 8$ & 748696 & 7177203 \\
\hline
\end{tabular}

Samples were collected on the surface of the seabed using a background search van Veen type stainless steel with a capacity of $0.007 \mathrm{~m} 3$ sample. Each sample was properly packaged and identified with a label consisting of sample station, parameter to be analyzed, preservation method and date. Samples were collected before dredging operation between $16-18$ th of January 2011 , as seen the location in table 3.

According to CONAMA 454/2012, number of samples necessary to characterize sediments is based on the area, volume to be dredged and previews knowledge about the dredge sediment (table 4).

Table 4. Number of samples according to the volume to be dredged.

\begin{tabular}{|c|c|}
\hline Volume to be dredged (m3) & Number of samples \\
\hline Until 25.000 & 3 \\
\hline $25.000-100.000$ & 4 until 6 \\
\hline $100.000-500.000$ & 7 until 15 \\
\hline $500.000-2.000 .000$ & 16 until 30 \\
\hline More than 2.000 .000 & 10 extras/1 million $\mathrm{m} 3$ \\
\hline
\end{tabular}




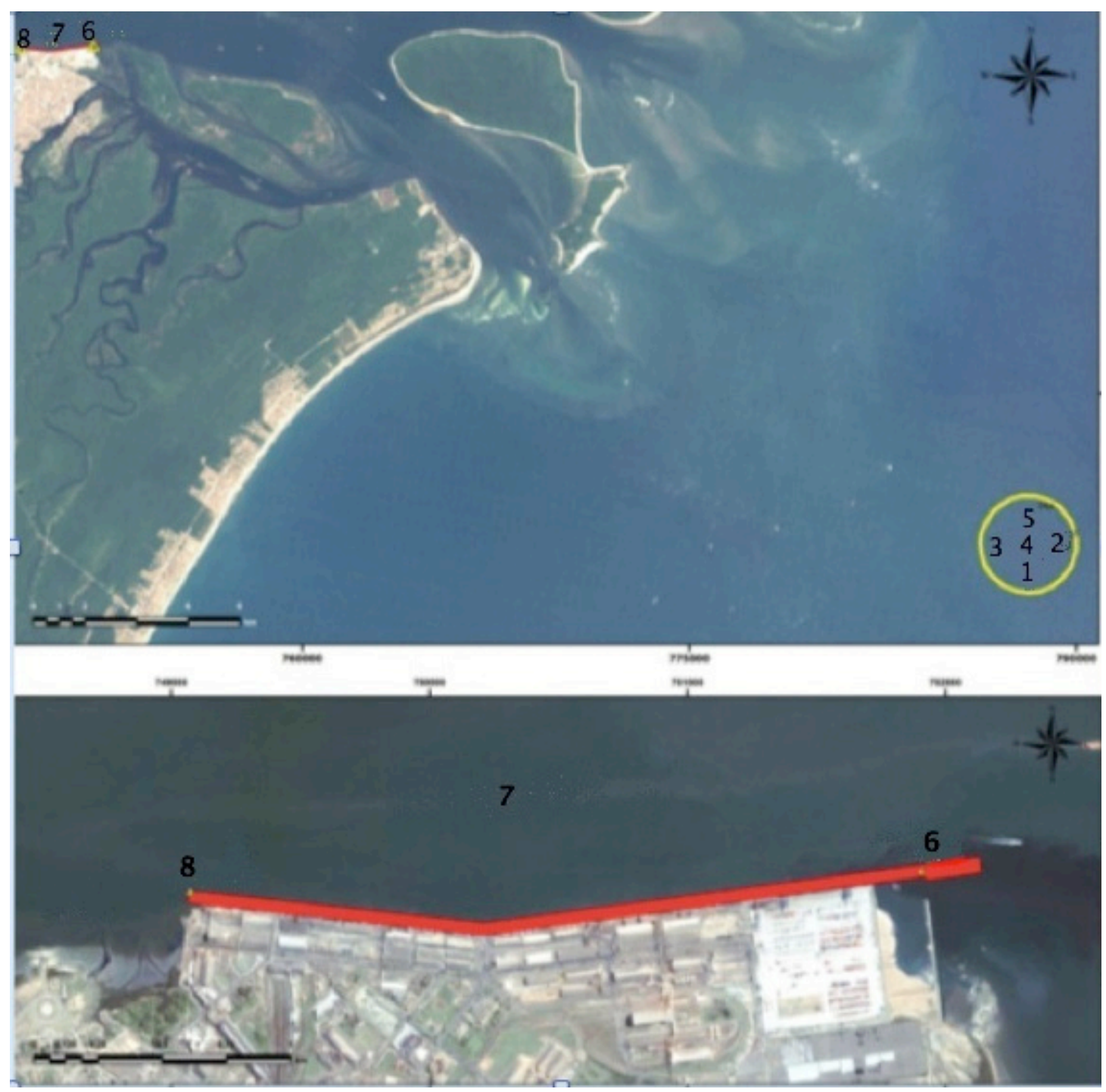

Figure 2. Location of samples in the disposal area $\# 1, \# 2, \# 3, \# 4, \# 5$ and in the berth area $\# 6, \# 7, \# 8$.

\subsection{Method}

Sample laboratory analyses were carried out by the Company Bioensaios Análises e Consultoria Ambiental S/C. It was analyzed only aspects of Arsenic (As); Mercury (Hg); Nickel (Ni); Zinc (Zn); Cadmium (Cd); Lead (Pb); Copper (Cu); Total phosphorus; Total Organic Carbon - TOC and Total Kjeldahl Nitrogen. Analytical methodology for the extraction of metals and semi-metals of sediment samples consisted of attack with mineral acids and heating, according to EPA SW 846.

\section{Results}

\subsection{Metals and Arsenic Composition}

Table 5 shows the results obtained for metals and arsenic concentrations in sediment samples $(\mathrm{mg} / \mathrm{kg})$ before dredging activity in the berths of Paranagua Port. 
Table 5. Results of metals and arsenic concentrations in sediment samples

\begin{tabular}{|c|c|c|c|c|c|c|c|c|}
\hline \multirow{10}{*}{ Before dredging } & \multicolumn{8}{|c|}{ Metals and arsenic (mg/kg) } \\
\hline & Sample & As & $\mathrm{cd}$ & $\mathrm{Pb}$ & $\mathrm{Cu}$ & $\mathrm{Hg}$ & $\mathrm{Ni}$ & $\mathrm{Zn}$ \\
\hline & $\# 1$ & $<2,5$ & $<0,5$ & $<2,5$ & $<2,5$ & ND & $<2,5$ & 3,0 \\
\hline & $\# 2$ & $<2,5$ & $<0,5$ & $<2,5$ & ND & ND & $<2,5$ & $<2,8$ \\
\hline & $\# 3$ & $<2,5$ & $<0,5$ & $<2,5$ & ND & ND & $<2,5$ & 3,1 \\
\hline & $\# 4$ & $<2,5$ & $<0,5$ & $<2,5$ & ND & $<0,15$ & $<2,5$ & $<2,5$ \\
\hline & $\# 5$ & $<2,5$ & $<0,5$ & $<2,5$ & $<2,5$ & $<0,15$ & $<2,5$ & 2,6 \\
\hline & $\# 6$ & $<2,5$ & $<0,5$ & 3,1 & $<2,5$ & $<0,15$ & 4,0 & 15,0 \\
\hline & $\# 7$ & $<2,5$ & $<0,5$ & 4,0 & $<2,5$ & $<0,15$ & 5,8 & 27,8 \\
\hline & $\# 8$ & 3,3 & $<0,5$ & 10,1 & 12,7 & $<0,15$ & 14,7 & 53,4 \\
\hline Conama & Level 1 & 19 & 1,2 & 46,7 & 34 & 0,3 & 20,9 & 150 \\
\hline $454 / 2012$ & Level 2 & 70 & 7,2 & 218 & 270 & 1,0 & 51,6 & 410 \\
\hline
\end{tabular}

Samples had concentrations below Level 1 established by CONAMA Resolution No. 454/2012.

We can interpret that Cadmium and Mercury results had no variation between disposal site and berth area. However, berth samples of Nickel, Zinc and Lead increased values comparing to disposal site results. The minimum value in berth samples compared to disposal site increased $60 \%, 500 \%$ and $24 \%$ respectively.

Samples of Copper and Arsenic showed different results only in sample \#8. Although result is bellow level 1, it increased $400 \%$ and $32 \%$ respectively, with values of $12,7 \mathrm{mg} / \mathrm{kg}$ and $3,3 \mathrm{mg} / \mathrm{kg}$, as seen on figure 6 and figure 3 .

Analyzing figures 8, 9 and figure 6, the maximum values were found in Nickel, Zinc and Copper with concentrations of $53,4,14,7$, and $12,7 \mathrm{mg} / \mathrm{kg}$, respectively, all of them in sample \#8.
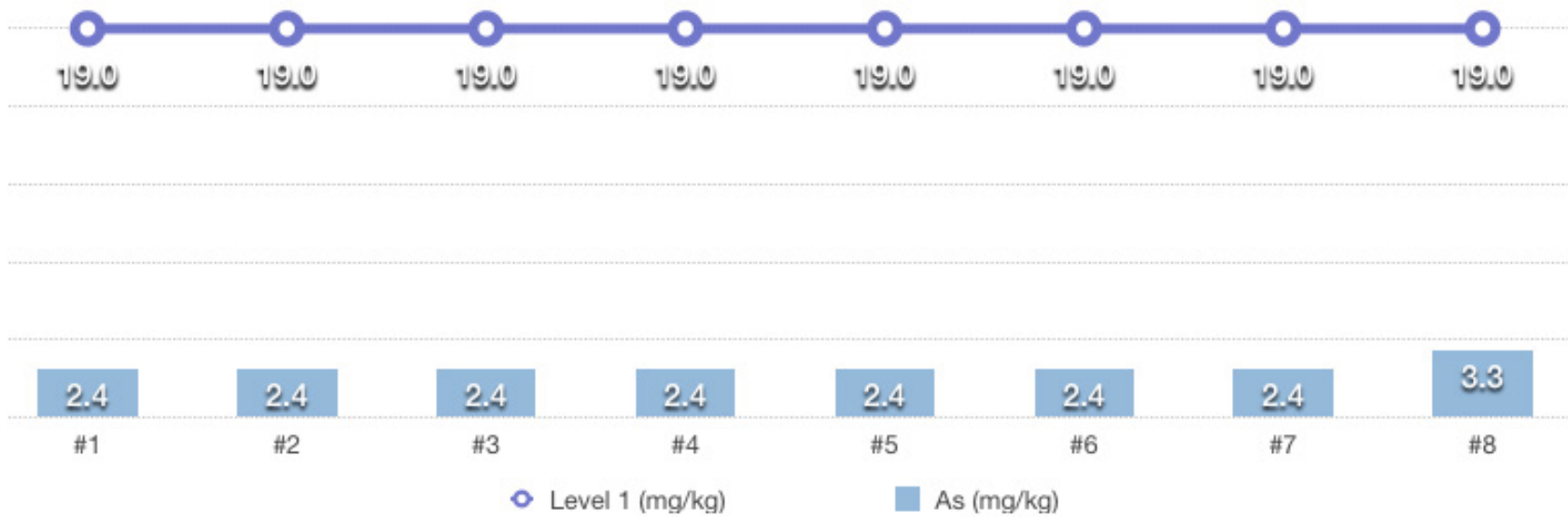

Figure 3. Results of arsenic concentrations in sediment samples.. Open cycle represents no variation in Arsenic samples results, exception to sample \#8 that increased $37 \%$.

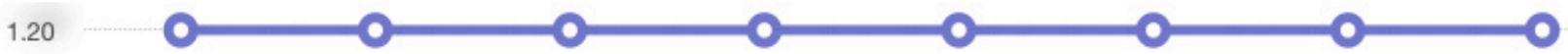

0.60

0.00

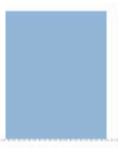

$\# 1$

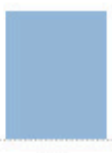

\#2

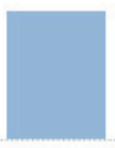

$\# 3$

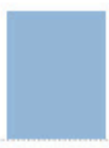

$\# 4$

․ Level 1 (mg/kg)

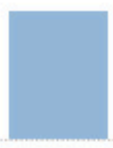

\#5

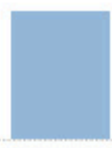

\#6

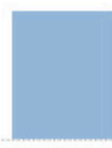

\#7

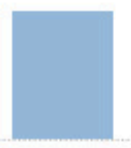

\#8

$\mathrm{Cd}(\mathrm{mg} / \mathrm{kg})$

Figure 4. Results of cadmium concentrations in sediment samples. Open cycle represents no variation on cadmium samples. 


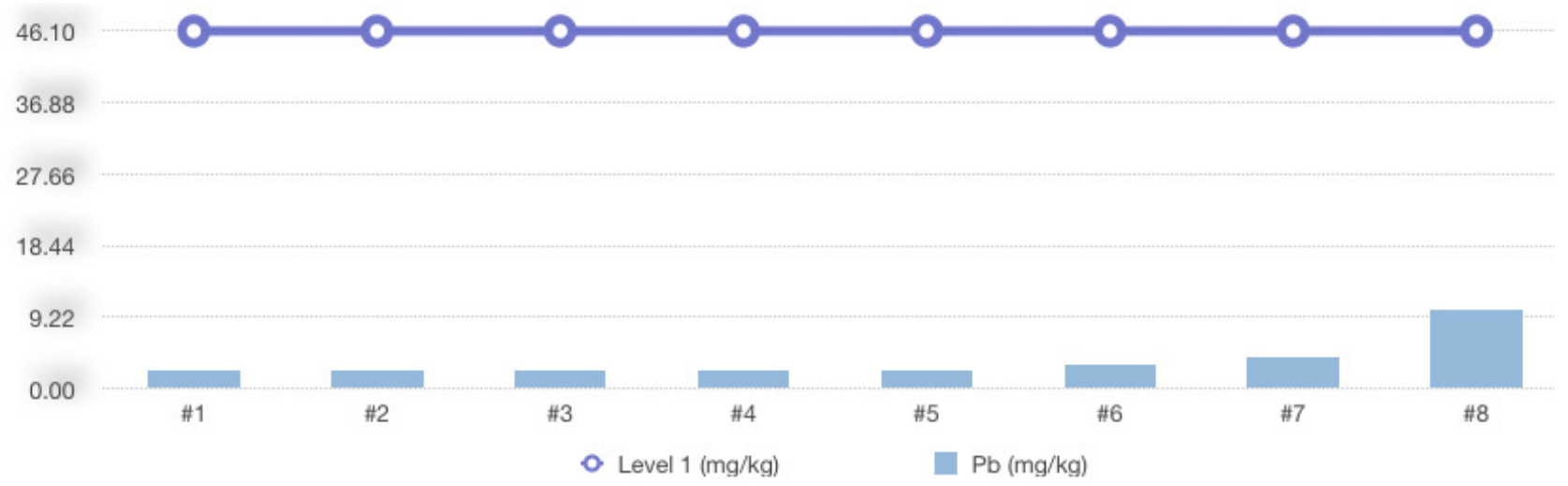

Figure 5. Results of Lead concentrations in sediment samples.

34.00

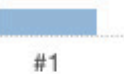

$\# 2$

\#3

\#4
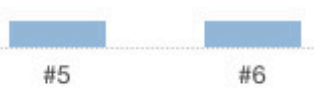

t7

- Level $1(\mathrm{mg} / \mathrm{kg})$

\#5

$\mathrm{Cu}(\mathrm{mg} / \mathrm{kg})$

Figure 6. Results of Copper concentrations in sediment samples.
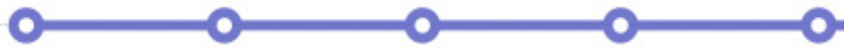

0.20

0.10

0.00

$\# 1$

\#2

\#3

○. Level $1(\mathrm{mg} / \mathrm{kg})$

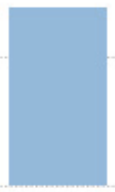

\#5

$\mathrm{Hg}(\mathrm{mg} / \mathrm{kg})$

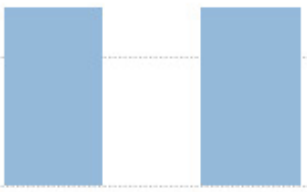

\#6

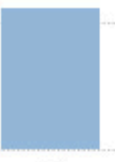

\#8

Figure 7. Results of Mercury concentrations in sediment samples.

20.90

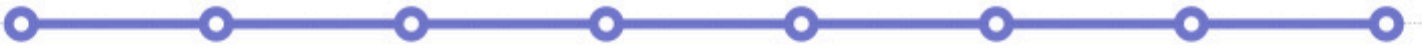

13.93

6.97

0.00
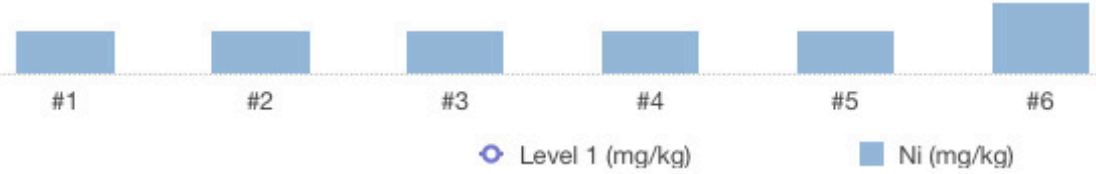

\#6

$\mathrm{Ni}(\mathrm{mg} / \mathrm{kg})$

Figure 8. Results of Nickel concentrations in sediment samples. 

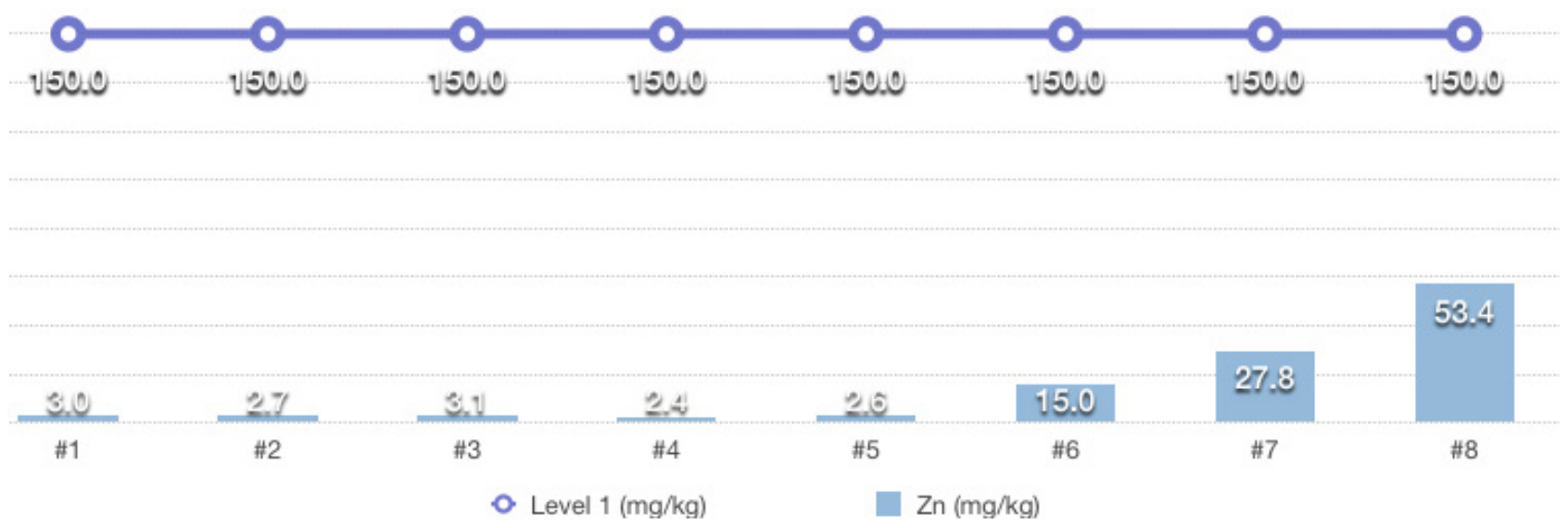

Figure 9. Results of Zinc concentrations in sediment samples.

Table 6. Results of Total Organic Carbon (TOC), Total Nitrogen (TN) and Total Phosphorus (TP)

\begin{tabular}{|c|c|c|c|c|}
\hline Sample & Period & TOC (\%) & TN (mg/kg) & $\mathrm{TP}(\mathrm{mg} / \mathrm{kg})$ \\
\hline$\# 1$ & \multirow{8}{*}{ Before Dredging } & 0,0834 & 60 & 40,8 \\
\hline$\# 2$ & & 0,0999 & 59 & 35,5 \\
\hline$\# 3$ & & 0,1496 & $<50$ & 42,11 \\
\hline$\# 4$ & & 0,117 & 59 & 44,1 \\
\hline$\# 5$ & & 0,1162 & $<50$ & 30,7 \\
\hline$\# 6$ & & 0,8677 & 178 & 131,3 \\
\hline$\# 7$ & & 0,841 & 448 & 277,6 \\
\hline$\# 8$ & & 3,917 & 2254 & 631,4 \\
\hline CONAMA 454/12 & Alert Value & 10 & 4800 & 2000 \\
\hline
\end{tabular}

\subsection{Total Organic Carbon, Total Nitrogen and Total Phosphorus}

Before dredging activity, concentrations results of total organic carbon, total phosphorus and nitrogen are presented on a consolidated basis in Table 6 .

Concentration of total organic carbon for all samples, both dredged area and disposal area, showed inferior results in the Alert value CONAMA 454/2012.

The highest Phosphorus value observed in the berth area sample \#8 was $631,40 \mathrm{mg} / \mathrm{kg}$, where there is a large input of organic matter and minimum verified was $30,7 \mathrm{mg} / \mathrm{kg}$, in disposal site sample \#5. Analyzing the results of total phosphorus concentration in sediment samples, there was a significant increase in the sampling station \# 8.631,4 mg/kg. This sampling station was collected in the western of Paranagua Port, with several nearby sources of phosphorus, as a fragment of mangrove and some drainage channels that receive untreated sewage flow into this region and, beyond the port operation itself by discharging fertilizer and grain loading. All of these sources may be responsible for the intake of phosphorus in the environment that has accumulated over time in the sediment.

Berth samples demonstrated through TOC analyzes, that fuel, oil terminals or pollution caused by ships increased results in that area. Minimum value in berth sample \#7 $(0,841 \%)$ was $462 \%$ higher than the maximum value in disposal site sample \#3 $(0,1496 \%)$

Total phosphorus, TOC and Total Nitrogen also had low results in the disposal area samples, as shown in sample \#5, $0,1162 \%,<50 \mathrm{mg} / \mathrm{kg}, 30,7 \mathrm{mg} / \mathrm{kg}$ respectively. In the other hand, in sample \#6 results, in the berth area, started to increase $0,8677 \%, 178 \mathrm{mg} / \mathrm{kg}, 131,3 \mathrm{mg} / \mathrm{kg}$ and had in sample \#8 the maximum result 3,917\%, 2254mg/ $\mathrm{kg}$ and $631,4 \mathrm{mg} / \mathrm{kg}$ respectively.

Total nitrogen ranged from maximal and minimum value $2254 \mathrm{mg} / \mathrm{kg}$ and $<50 \mathrm{mg} / \mathrm{kg}$, respectively. The highest total nitrogen in sediments was in sample \#8, while the lowest was in sample \#3 and \#5. However, total nitrogen results in sediments for all the samples not exceeded the level of reference.

\section{Discussion}

Worldwide each year several hundred million cubic meters are dredged where much of this sediment is removed from ports that present constant silting, generated by natural or anthropogenic, active actions. The environmental impacts associated with dredging and disposal of dredged material process can be characterized by exhibiting direct, indirect, 
attributed to changes in water quality, effects on habitats and organisms [13].

Contaminated sediment typically contains a mixture of various contaminants [14], which can interact among themselves antagonistic or additive manner to produce unknown effects on the ecosystem. This situation is quite critical in Brazil, because often the dumping of domestic and industrial effluents is not controlled and thus does not consider the issue of protection of the environment [15]; [16], mainly in adjacent coastal areas of urban perimeters. Often, the nature of these discharged substances is unknown, as well as eco-toxicological consequences of its presence in the environment. That is one of the reasons that although all samples results, both from dredged area and disposal area, showed inferior results in the Alert value CONAMA 454/2012, we can consider that $\mathrm{Ni}, \mathrm{Zn}, \mathrm{Cu}, \mathrm{Pb}$, As, TOC, Total Nitrogen and Total Phosphorus had values increased in the berth area.

Especially in sample \#8, most of contamination may come from industries activities, fertilizer and pesticides as Paranagua Port exports grains and imports fertilizer and pesticides to control food production. Some soils that are used to produce grains are deficient in the heavy metals (such as $\mathrm{Co}, \mathrm{Cu}, \mathrm{Fe}, \mathrm{Mn}, \mathrm{Mo}, \mathrm{Ni}$, and $\mathrm{Zn}$ ) that are essential for healthy plant growth, and crops may be supplied with these as an addition to the soil as a fertilizer. Several common pesticides used fairly extensively in agriculture and horticulture contain substantial concentrations of metals $\mathrm{Cu}$, $\mathrm{Hg}, \mathrm{Mn}, \mathrm{Pb}$, or $\mathrm{Zn}$.

High arsenic concentrations may result of weathering and due to certain human activities, including metal mining, smelting and fossil fuel combustion.

Zinc concentration sample suggest that it may come from mining, smelting (metal processing, like zinc, lead and cadmium) activities and steel production. High levels of zinc are often found along with high levels of other metals like lead and cadmium. Exposure to high levels of zinc over long periods of time may cause adverse health effects. Municipal and industrial wastewater and related effluents may also contribute to metal concentrations in sediments, [17].

On the continuous interaction between water and sediment, Adams et al. [18] mentioned that the protection of sediment quality has been seen as an extension of water quality, since in addition to its importance as a habitat for many aquatic organisms, sediments may also be the largest deposit of persistent chemicals introduced into environment.

$\mathrm{Zn}, \mathrm{Cu}, \mathrm{Ni}$ and $\mathrm{Pb}$ are the elements that can cause more health and environmental adverse effects. The main source of $\mathrm{Zn}, \mathrm{Cu}$, Ni may be carried by partly treated, industrial and municipal wastewaters, agrochemicals and landfill leachates. Solid and liquid wastes resulting from urban areas are enriched with $\mathrm{Cu}, \mathrm{Pb}, \mathrm{Zn}$ and $\mathrm{Ni}$, while $\mathrm{Cu}, \mathrm{Pb}, \mathrm{Zn}, \mathrm{Cr}$, Ni are constituents of agrochemicals [19]. The study of these elements in sediments plays an important role in studying the environmental capacity of sediments in that reach, providing fundamental data for government departments, which may be able to implement measures of controlling and target management, protecting human health and improving environment in Paranagua Port.

\section{Conclusions}

The analytical results in this paper were compared to CONAMA 454/2012 values as a screening tool to estimate the relative degree of contamination. With these results we can conclude that all samples collected BEFORE dredging were found below the levels of prevention and investigation of CONAMA 454/2012. However, considering the nature of these contaminations, we can suggest that losses during the operations of loading / unloading, storage and transfer of chemicals in Paranagua Port, constitute sources of polluting materials into waters of the estuarine system of Paranagua. These losses may also occur beyond the harbor, across its proximity where there are warehouses, silos, storage tanks for fuel, oil terminals and etc. In addition, there is also the pollution caused by ships' crews, for their maintenance with cleaning up basements and leaching of hooves and paints, [20].

Regarding monitored nutrients, Total Phosphorus showed a significant change between berth samples and disposal site samples. Berth samples are located near the mouth of canals and waterways that run through densely populated area and it is known that wastewater represents an important contribution to the intake of phosphorus for marine and estuarine environments. In urban areas, rainwater drainage, combined with the weakness of the public sanitation system, diffuse source is difficult to characterize. The sewage treatment processes currently used in Brazil do not include the removal of nutrients and treated final effluent release high concentrations of nutrients in water bodies.

This work focused on the determination of trace elements in the area to be dredged and area to be disposed in order to evaluate characteristics of sediments before dredging. Results of chemical analyses show that beneficial use of dredged material is technically feasible. It poses no significant impacts on human health and potential contaminant released by effluent and runoff poses small environmental impacts that should be acceptable with proper operation, management and control.

Coata et al. [21] suggested to build up habitat restoration using dredged material. According to USACE [22] there are seven categories based on their potential to complement and contribute to ongoing restoration activities in the Harbor, and their ability to accommodate significant placement capacity for material derived from ongoing and planned dredging activities. These include: creation of artificial reefs and shoals, oyster reef restoration, bathymetric recontouring, creation/restoration of intertidal marshes and mudflats, filling dead-end basins and canals, creation of bird/wildlife islands, remediation/creation of upland habitats (landfill/brownfields reclamation), [23].

The results of chemical characterization indicate that dredged material is suitable for disposal at sea. But in the other hand, the potential value of dredged material as a 
resource can be considered the availability of beneficial use.

Beach nourishment has been a solution for replacing lost sediment by coastal erosion, big concern to solve erosion problems in beaches near Paranagua Port. Dredged material suitable for beach nourishment, generally must be comprised of at least 80 percent sand or demonstrate a similar grain size distribution to that of the receiving beach (sand content within a 10 percent difference), and have low or background levels of chemical contamination [24].

Goes Filho [25] highlights that the beneficial use of dredged material is directly related to its composition and particle size distribution so it is necessary to know these parameters to set the final destination.

Therefore, grain size distribution must be analyzed in order to check feasibility to use dredge material as beach nourishment, avoiding unwanted effects on topography, bathymetry and biota associated with this environment, USEPA [23].

\section{REFERENCES}

[1] BRAY, R. N; BATES, A. D. \& LAND, J. M., Dredging, a Handbook for Engineers. Second Edition. New York: John Wiley \& Sons, 1997.

[2] IADC, International Association of Dredging Companies, available in: http://www.iadc-dredging.com/ul/cms/fck-uploa $\mathrm{ded} /$ documents/PDF\%20Publications/dredging-literature-dred ging-the-facts.pdf. Accessed in 5-11-2012.

[3] USACE, USEPA. Beneficial uses of dredged material, http://www.wes.army.mil/el/dots/budm/index.html. Accessed in 2011-12-27.

[4] HUANG Huamei, GAO Yang, WANG Yinxia, LOU Quansheng, XIE Jian*. Review of the current situation of coastal ecological engineering using dredged marine sediments and prospects for potential application in China。 Acta Ecologica Sinica, 2012, 32(8):2571-2580.

[5] PEREIRA,M.E.;Duarte,A.C.;Millward,G.E.;Abreu,S.N.;Vale, C.;Water. Sci. Techol. 1998, 37, 125.

[6] ARORA, B.R., Azad, A.S., Singh, B. \& Sekhon, G.S. (1985). Pollution potential of municipal waste waters of Ludhiana, Punjab. Indian Journal of Ecology, 12: 1-7.

[7] BRIDGES CC, Zalups RK. Molecular and ionic mimicry and the transport of toxic metals. Toxicol Appl Pharmacol. 2005;204:274-308.

[8] CI Jun. (1969). Minamata disease and water pollution on industrial wastes. Review International Ocean Organisations. Med. Nos. 13-14.

[9] CASTIGLIA, M. C. C. P. Disposição subaquática de rejeitos de dragagem: o caso do complexo lagunar de Jacarepaguá. Rio de Janeiro, Dissertação (Mestrado em Engenharia Civil) COPPE/UFRJ, 2006.

[10] CONAMA. 2012. CONSELHO NACIONAL DO MEIO AMBIENTE. Resolução N 454 - 01 de novembro de 2012. Conselho Nacional do Meio Ambiente. Brasília, DF. 2012.

[11] APPA. Infrastructure of Paranagua Port. Available in: http://www.portosdoparana.pr.gov.br/modules/conteudo/cont eudo.php?conteudo=38 Accessed in 15-05-2014.

[12] COELHO, G.G.; MATOS, F.S.; OLIVEIRA, B.; ALCÂNTARA, A.V.; SCHER, R.; PANTALEÃO, S.M. Avaliação do impacto genotóxico de poluentes químicos presentes nos sedimentos do Rio do Sal por meio de análises de aberrações cromossômicas (AC) na espécie Allium cepa. Resumos do 55o CongressoBrasileiro de Genética. 30 de agosto a 02 de setembro de 2009. Centro de Convenções do Hotel Monte Real Resort. Águas de Lindóia. SP. Brasil.

[13] KENNISH, M. J. (ed.). Pratical handbook of marine Science. Boca Raton:. CRC Press, 1994. 556p. Available in: $<$ http://www.sblimno.org.br/acta/my_web_sites/acta_limnolo gica_contents 1402E_files/Artigo\%2010_14(2).pdf $>$. Accesse d in $10-3-2014$.

[14] SWARTZ, R.C., KEMP, P.F., SCHULTZ, D.W., LAMBERSON, J.O., 1988. Effects of mixtures of sediment contaminants on the marine infaunal amphipod, Rhepoxynius abronius. Environ. Toxicol. Chem. 7:1013-1020.

[15] TOMMASI, L.R., 1987. Impacto da disposição oceânica de esgotos municipais no ambiente costeiro: uma síntese. Engenharia Sanitária 26 (4), 412-418.

[16] GONÇALVES, F.B.; SOUZA. M., 1997. Disposição oceânica de esgotos sanitários: história, teoria e prática. Multiservice Engenharia. Associação Brasileira Sanitária e Ambiental-ABES.Rio de Janeiro :1997

[17] RAYMOND A. Wuana, Felix E. Okieimen, Heavy Metals in Contaminated Soils: A Review of Sources, Chemistry, Risks and Best Available Strategies for Remediation; Ecology, Volume 2011 (2011), Article ID 402647, 20 pages.

[18] ADAMS, W.J., KIMERLE, R.A., BARNETT, J.W. Jr., 1992. Sediment quality and aquatic life assessment. Environ. Sci. Technol. 26:1863-1876.

[19] FORSTNER, U. \& G. T. W. Wittmann, 1981, Metal Pollution in the Aquatic Environment. Springer, Berlin, Heidelberg, New York.

[20] HORTELLANI Marcos Antonio, Sarkis Jorge E. S., Abessa Denis M. S., Sousa Eduinetty C. P. M.. Avaliacao da Contaminacao por Elementos Metalicos dos Sedimentos do Estuario Santos- Sao Vicente. Quim. Nova, 2008, 31(1):10-19.

[21] COATA-Pierce B A, Weinstein M P. Use of dredge materials for coastal restoration. Ecological Engineering, 2002, 19:181-186.

[22] U.S. Army Corps of Engineers/Engineer Research and Development Center (2007). "Summary of Available Guidance and Best Practices for Determining Suitability of Dredged Material for Beneficial Uses, "ERDC/EL TR-07-27, Washington, DC.

[23] YOZZO David J. , Pace Wilber', Robert J. Will, Beneficial use of dredged material for habitat creation, enhancement, and restoration in New York-New Jersey Harbor, Journal of Environmental Management, 2004, 73(1): 39-52.

[24] USEPA. 1998. Evaluation of Dredged Material Proposed for Discharge in Waters of the U.S. Testing Manual. EPA 823-B-98-004.

[25] GOES FILHO, H. A. Dragagem e Gestão de Sedimentos. Dissertação de Mestrado em Engenharia Civil, COPPE/UFRJ, Rio de Janeiro. 2004. 